\title{
IMPACT OF CONVERTING AREAS CULTIVATED WITH SUGARCANE TO EUCALYPT PLANTATIONS ON SOIL QUALITY IN NORTHEASTERN BRAZIL
}

\author{
Aldair de Souza Medeiros $2^{*} \cdot$, Rener Luciano de Souza Ferraz ${ }^{3}$ ㄱ, Thamirys Suelle da Silva ${ }^{4}$, \\ Anderson Vitor Lins da Silva ${ }^{5}$ and Stoécio Malta Ferreira Maia ${ }^{6}$ (C)
}

\footnotetext{
${ }^{1}$ Received on 09.12.2020 accepted for publication on 09.04.2021.

${ }^{2}$ Universidade de São Paulo, Departamento de Ciência do Solo, Piracicaba, SP - Brasil. E-mail: <aldairmedeiros@gmail.com>.

${ }^{3}$ Universidade Federal de Campina Grande, Unidade Acadêmica de Tecnologia do Desenvolvimento, Sumé, PB - Brasil. E-mail: $<$ ferragroestat@gmail.com>.

${ }^{4}$ Universidade Federal Rural de Pernambuco, Programa de Pós-Graduação em Engenharia Ambiental, Recife, PE - Brasil. E-mail: $<$ thamiryssuelle@hotmail.com>.

${ }^{5}$ Universidade Federal de Alagoas, Programa de Pós-Graduação em Agronomia, Rio Largo, AL - Brasil. E-mail: <anderson.vytor@ hotmail.com>.

${ }^{6}$ Instituto Federal de Alagoas, Marechal Deodoro, AL - Brasil. E-mail: <stoecio.maia@ifal.edu.br>.

${ }^{*}$ Corresponding author.
}

\begin{abstract}
Reforestation is considered an effective method to improve soil quality and drain atmospheric $\mathrm{CO}_{2}$ by sequestering carbon, in both soil and vegetation. In this regard, the aim of this study was to evaluate the effects of converting areas cultivated with sugarcane to eucalypt plantations (Eucalyptus spp.) on soil quality and carbon sequestration in a Latossolo (Ferralsol) in the Atlantic Forest region of the Alagoas state, Brazil, through multivariate analysis. The systems under evaluation consisted of four areas: one area cultivated with sugarcane for approximately 20 years, taken as the reference area of this study, and the other three adjacent areas cultivated with eucalypt at 1 (E1), 3 (E3) and 6 (E6) years of age, previously cultivated with sugarcane. Physical (bulk density - BD, Mean weight-diameter - MWD, geometric mean diameter - GMD and aggregate stability index - ASI), chemical (soil organic carbon - SOC, total nitrogen - TN, labile carbon - LC and recalcitrant carbon - RC) and biological (Microbial biomass carbon - MBC, soil carbon respiration - C-CO and metabolic quotient $-\mathrm{qCO}_{2}$ ) properties of soil were evaluated. Data were collected, standardized and submitted to exploratory analysis with principal components. The results show that SOC, LC, TN, GMD, MWD and ASI increased, while BD showed a reduction in E3 and E6 systems. The conversion of sugarcane cultivation with burning of straw and manual harvest into eucalypt plantations was efficient at promoting SOC sequestration and improving physical, chemical and biological properties of soil.
\end{abstract}

Keywords: Carbon sequestration; Land-use; Principal component analysis.

\section{IMPACTO DA CONVERSÃO DE AREAS CULTIVADAS COM CANA-DE-AÇÚCAR EM PLANTAÇÕES DE EUCALIPTO NA QUALIDADE DO SOLO NO NORDESTE DO BRASIL}

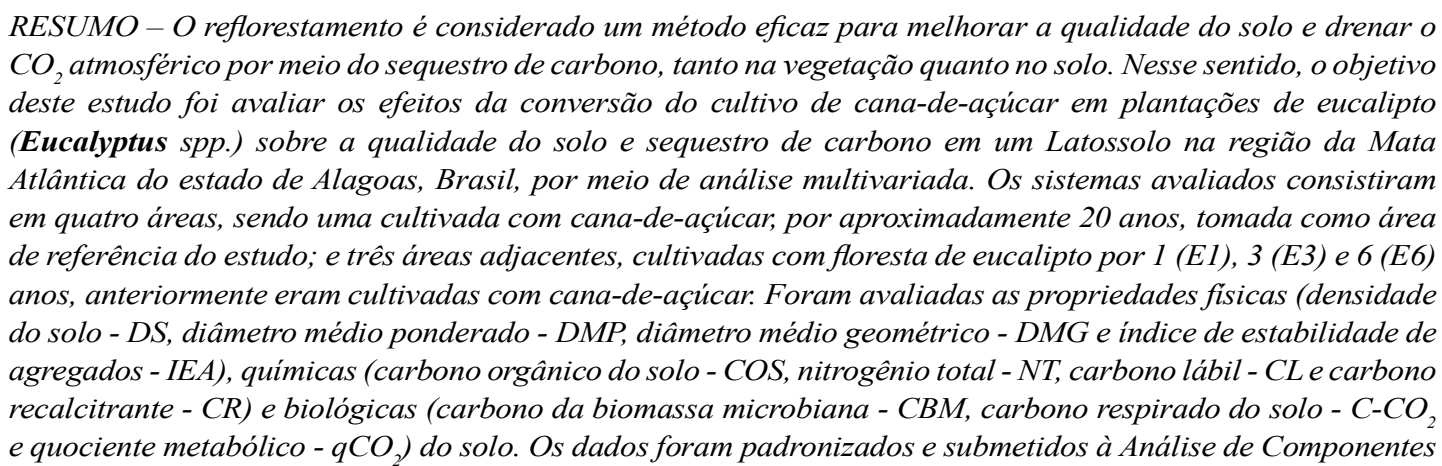


Principais. Os resultados mostram que COS, CL, NT, DMG, DMP e IEA aumentaram, enquanto DS apresentou redução nos sistemas E3 e E6. A conversão do cultivo de cana-de-açúcar com queima da palhada e colheita manual para plantações de eucaliptos foi eficiente em promover o sequestro de COS e melhorar as propriedades fisicas, químicas e biológicas do solo.

Palavras-Chave: Sequestro de carbono; Uso da terra; Análise de componentes principais.

\section{INTRODUCTION}

Demand for forest products mirrors the world exponential population growth (Guedes et al., 2018). Thus, in the face of global limitations of native forest reserves, planted forests have gradually expanded in several regions worldwide. Species of the genus Eucalyptus spp. are the most cultivated, occupying an area of more than 19 million hectares worldwide (Cavalli et al., 2020). In Brazil, eucalypt plantation (Eucalyptus spp.) occupies an area of approximately 6 million hectares (Souza et al., 2020).

In the northeast of Brazil, state of Alagoas, areas cultivated with sugarcane (main economic activity) have been losing ground to eucalypt plantation (Medeiros et al., 2018), and around 14 thousands hectares are cultivated with this crop. This change is due to several factors, including the depreciation of ethanol (17\%) and sugar (27\%) prices, competing with south-central region (CONAB, 2016), and, mostly, due to forestry growth, which is responsible for an annual value of US\$ 7 billion in Brazil (IBÁ, 2017).

Historically, eucalypt plantations provide charcoal, firewood, wood, cellulose and biomass for energy generation (Korchagin et al., 2019). Furthermore, these forests contribute to the environmental conservation, since they improve soil quality, release lower levels of greenhouse gases (GHG) and are natural carbon sinks (Zhang et al., 2019; Souza et al., 2020). Eucalypt trees deposit organic residue on soil, which contributes to an increase in soil organic matter (SOM) and, consequently, in soil organic carbon (SOC) content over time (Vicente et al., 2019). However, SOC content in eucalypt areas depend on a several factors such as type, layer and mineralogy of soil, climate conditions, growing time, management practices, among others (Hernández et al., 2016; Korchagin et al., 2019; Zhang et al., 2019; Cavalli et al., 2020).
In this regard, Guedes et al. (2016) observed in Mozambique that eucalypt plantations (Eucalyptus spp.) altered nutrient quantity, $\mathrm{pH}$ and physical properties of soil in comparison to a native forest. Likewise, Vicente et al. (2019) state that soil macroaggregates $(2000-250 \mu \mathrm{m})$ prevail over microaggregates $(250-53 \mu \mathrm{m})$ in eucalypt areas (Eucalyptus spp.) in the southeast region of Brazil. On the other hand, Gama-Rodrigues et al. (2008), in the same region of Brazil, did not find significant differences for microbial biomass carbon and metabolic quotient in eucalypt area (Eucalyptus spp.) and native forest.

In general, eucalypt reforestation improves physical, chemical and biological properties of soil (Guedes et al., 2016; Medeiros et al., 2018; Korchagin et al., 2019; Vicente et al., 2019; Cavalli et al., 2020; Souza et al., 2020), but literature review is limited when it comes to the effects found in the transition from sugarcane cultivation to eucalypt plantations. Moreover, in general, the assessment of soil quality requires the use of a large number of variables, which in most cases makes research unfeasible due to financial, logistical or operational reasons (Hair et al., 2009). Thus, the use of multivariate analysis can facilitate this process. This technique has been used to improve the understanding of variations in soil quality properties promoted by changes in land-use or management (Govaerts et al., 2007; Hair et al., 2009). Therefore, the aim of this study was to evaluate the effects of converting areas cultivated with sugarcane to eucalypt plantations (Eucalyptus spp.) on soil quality and carbon sequestration in a Latossolo (Ferralsol) in the Atlantic Forest region of the Alagoas state, Brazil, through multivariate analysis.

\section{MATERIALS AND METHODS}

\subsection{Study area and soil sampling}

The study was conducted on a rural property in the Forest Zone of the district of Atalaia, state of

Revista Árvore 2021;45:e4517 
Alagoas, Brazil. The municipality is located in the Eastern Mesoregion of the state (09²6'56.6" S and $\left.36^{\circ} 00^{\prime} 30.8^{\prime \prime} \mathrm{W}\right)$. According to Köppen (1918), the climate in the region is tropical warm (As'), with a mean annual temperature of $27{ }^{\circ} \mathrm{C}$ and autumn/ winter rainfall between 1,000 and $1,500 \mathrm{~mm}$, welldistributed throughout the year. The soil in the study area was classified as a Latossolo with a clayey texture (EMBRAPA, 2012), Ferralsol according to the classification of IUSS Working Group WRB-FAO (2015).

The study areas were selected taking into consideration the homogeneity of the soil characteristics, the relief and their relative proximity. The systems evaluated consisted of four areas: an area of 5.0 ha, cultivated with sugarcane (SC) for approximately 20 years, always under a conventional system of soil tillage, with straw burning and manual harvesting (considered the original condition of the soil as reference) and three adjacent areas, measuring $2.5,3.0$ and 1.5 ha, cultivated with eucalypt forest (Eucalyptus spp.) at one (E1), three (E3) and six (E6) years of age, respectively. The areas of eucalypt had previously been cultivated with sugarcane under a conventional system for about 20 years. Preparation of the areas of eucalypt was conventional, with liming incorporated by harrowing and deep subsoiling (80$100 \mathrm{~cm}$ ), followed by basal phosphate fertilization; and then, the eucalypt seedlings (Clones 224 and 1407) were transplanted into holes spaced $3.5 \times 2.5$ $\mathrm{m}$ apart.

Soil samples were collected in June and July of 2015 by opening five 90 -cm-deep soil pits in each area. The soil pits were opened randomly between the rows and considered as replicates, giving a total of 120 samples. Disturbed soil samples and undisturbed soil samples were collected between the planting rows at depths of $0-10,10-20,20-30,30-40,40-60$ and $60-$ $80 \mathrm{~cm}$.

\subsection{Soil analysis}

Bulk density (BD) was determined using the volumetric ring method (EMBRAPA, 1997). Soil samples were air-dried and sieved with a 2-mm mesh to remove stones and root fragments before analysis. The SOC content was determined by the wet oxidation method (Yeomans and Bremner, 1988). For each soil layer, we calculated the SOC stock by multiplying the concentration of $\mathrm{C}\left(\mathrm{g} \mathrm{g} \mathrm{g}^{-1}\right)$ by $\mathrm{BD}\left(\mathrm{kg} \mathrm{cm}^{-3}\right)$ and layer thickness (cm) (Sisti et al., 2004). To calculate the total SOC stock, the equivalent soil mass (ESM) approach was adopted to depths of 0-30, 0-60 and $0-80 \mathrm{~cm}$, following the procedure described by Sisti et al. (2004). The soil under sugarcane was used as a reference for the ESM approach.

Total nitrogen (TN) was quantified by sulfuric acid digestion (Tedesco et al., 1995). Labile carbon (LB) and recalcitrant carbon ( $\mathrm{RC}$ ) were obtained through different concentrations of $\mathrm{H}_{2} \mathrm{SO}_{4}$, as according to the methodology by Chan et al. (2001). Microbial biomass carbon (MBC) was determined at depths of 0-10, 1020 and $20-30 \mathrm{~cm}$ using the irradiation and extraction method (Islam and Weil, 1998; Ferreira et al., 1999; Mendonça and Matos, 2005). It was quantified by wet oxidation (Yeomans and Bremner, 1998) without an external heating source and a conversion factor (Kc) used to convert carbon flux to MBC of 0.33 (Sparling and West, 1998).

To quantify soil carbon respiration $\left(\mathrm{C}-\mathrm{CO}_{2}\right)$, a laboratory test was carried out with soil from the depths of $0-10,10-20$ and $20-30 \mathrm{~cm}$, considering $\mathrm{CO}_{2}$ evolution, which is produced by soil microbes, captured in $0.5 \mathrm{~N} \mathrm{NaOH}$ solution (Anderson, 1982). For this purpose, $50 \mathrm{~g}$ of soil were put in glass pots and aerobically preincubated for 7 days, in order to reestablish the microbial activity of soil. Soil moisture was kept at $80 \%$ field capacity. After the period of preincubation of samples, the pots received $20 \mathrm{~mL}$ of $0.5 \mathrm{~mol} \mathrm{~L}^{-1} \mathrm{NaOH}$ solution and were hermetically closed to capture $\mathrm{CO}_{2}$ and were only opened in case of $\mathrm{NaOH}$ change. Metabolic quotient $\left(\mathrm{qCO}_{2}\right)$ was obtained through the division of $\mathrm{C}-\mathrm{CO}_{2}$ released per day by $\mathrm{MBC}\left(\mathrm{mg} \mathrm{CO} \mathrm{mg}^{-1} \mathrm{MBC}\right.$ day $\left.^{-1}\right)$ at depths of $0-10,10-20$ and $20-30 \mathrm{~cm}$.

In order to evaluate the distribution of waterstable aggregates in soils, the method proposed by EMBRAPA (1997) was adopted, which uses the following diameter classes: 4.76-2.0 mm, 2.0-1.0 $\mathrm{mm}, 1.0-0.50 \mathrm{~mm}, 0.50-0.25 \mathrm{~mm}$ and $<0.25 \mathrm{~mm}$. Data of dry mass were used to calculate weighted mean diameter (MWD), geometric mean diameter (GMD) and aggregate stability index (ASI), according to methodology proposed by Ibiapina et al. (2014).

\subsection{Statistical analysis}

The treatments corresponded to the four land-use systems (SC, E1, E3 and E6), and the results were 
submitted to Bartlett's test for homogeneity and the Kolmogorov-Smirnov test for normality. Data were standardized $\left(\mathrm{X}^{\prime}=0.0\right.$ and $\left.\mathrm{s}^{2}=1.0\right)$ and submitted to principal component analysis (PCA), calculating linear combinations of original variables obtained through eigenvalue higher than the unit $(\lambda>1.0)$ in correlation matrix, which could explain a percentage higher than $10 \%$ of total variance (Govaerts et al., 2007).

Only the variables with a correlation quotient higher than 0.70 were kept in the composition of each principal component (PC) (Hair et al., 2009).
Variables that were not associated with PCs $(\mathrm{r}<0.70)$ were removed from standardized database and a new analysis was applied. Afterwards, each principal component was submitted to multivariate analysis of variance (MANOVA) by Hotelling's $\mathrm{T}^{2}$ test. All statistical analyses were performed using the Statistica software (STATSOFT, 2004).

In relation to $\mathrm{SOC}$ stock, the mean values considering the layers $0-30,0-60$ and $0-80 \mathrm{~cm}$ of the land-use systems were compared by Tukey's test ( $\mathrm{p}$ $<0.05)$.

Table 1 - Physical, chemical and biological parameters of soil in different layers in areas under sugarcane and eucalypt cultivation in the Atlantic Forest region of the state of Alagoas, Brazil.

Tabela 1 - Parâmetros físicos, químicos e biológicos do solo em diferentes camadas do solo em áreas sob cultivos de cana-de-açúcar e eucalipto na região da Mata Atlântica do estado de Alagoas, Brasil.

\begin{tabular}{|c|c|c|c|c|c|c|c|c|c|c|c|}
\hline \multirow{2}{*}{$\begin{array}{l}\text { Land-use } \\
\text { systems }\end{array}$} & \multicolumn{11}{|c|}{ Variables } \\
\hline & $\mathrm{BD}$ & $\mathrm{SOC}$ & $\mathrm{TN}$ & $\mathrm{LC}$ & $\mathrm{RC}$ & $\mathrm{MBC}$ & $\mathrm{qCO}_{2}$ & $\mathrm{C}-\mathrm{CO}_{2}$ & MWD & GMD & ASI \\
\hline & \multicolumn{11}{|c|}{$0-10 \mathrm{~cm}$} \\
\hline$\overline{\mathrm{SC}}$ & 1.36 & 1.84 & 0.08 & 1.00 & 0.78 & 0.09 & 0.33 & 0.14 & 1.66 & 1.47 & 82.97 \\
\hline E1 & 1.44 & 2.01 & 0.06 & 0.98 & 0.73 & 0.06 & 3.39 & 0.24 & 2.27 & 1.55 & 78.98 \\
\hline E3 & 1.29 & 2.38 & 0.09 & 1.10 & 1.05 & 0.05 & 1.25 & 0.25 & 2.55 & 1.57 & 88.97 \\
\hline \multirow[t]{2}{*}{ E6 } & 1.23 & 2.36 & 0.11 & 1.42 & 0.85 & 0.07 & 0.70 & 0.26 & 2.32 & 1.55 & 86.44 \\
\hline & \multicolumn{11}{|c|}{$10-20 \mathrm{~cm}$} \\
\hline $\mathrm{SC}$ & 1.31 & 1.77 & 0.08 & 0.77 & 0.75 & 0.04 & 0.73 & 0.16 & 1.75 & 1.50 & 82.56 \\
\hline E1 & 1.40 & 1.68 & 0.06 & 0.71 & 0.79 & 0.04 & 2.44 & 0.27 & 2.16 & 1.52 & 88.11 \\
\hline E3 & 1.26 & 2.15 & 0.08 & 1.00 & 0.86 & 0.04 & 1.24 & 0.24 & 2.12 & 1.54 & 87.45 \\
\hline \multirow[t]{2}{*}{ E6 } & 1.20 & 2.10 & 0.10 & 1.15 & 0.68 & 0.16 & 0.13 & 0.14 & 2.36 & 1.55 & 88.03 \\
\hline & \multicolumn{11}{|c|}{$20-30 \mathrm{~cm}$} \\
\hline $\mathrm{SC}$ & 1.31 & 1.48 & 0.05 & 0.74 & 0.53 & 0.05 & 0.47 & 0.11 & 1.86 & 1.50 & 85.46 \\
\hline E1 & 1.36 & 1.40 & 0.06 & 0.80 & 0.46 & 0.10 & 0.65 & 0.23 & 2.03 & 1.51 & 90.62 \\
\hline E3 & 1.19 & 1.78 & 0.06 & 0.97 & 0.55 & 0.08 & 0.69 & 0.22 & 2.04 & 1.51 & 92.49 \\
\hline \multirow[t]{2}{*}{ E6 } & 1.20 & 1.82 & 0.10 & 0.94 & 0.51 & 0.07 & 1.48 & 0.13 & 2.26 & 1.54 & 85.32 \\
\hline & \multicolumn{11}{|c|}{$30-40 \mathrm{~cm}$} \\
\hline $\mathrm{SC}$ & 1.35 & 1.19 & 0.05 & 0.61 & 0.31 & - & - & - & 1.87 & 1.51 & 85.13 \\
\hline E1 & 1.28 & 1.00 & 0.04 & 0.59 & 0.31 & - & - & - & 2.02 & 1.51 & 87.94 \\
\hline E3 & 1.26 & 1.32 & 0.07 & 0.69 & 0.31 & - & - & - & 2.07 & 1.53 & 90.16 \\
\hline \multirow[t]{2}{*}{ E6 } & 1.20 & 1.60 & 0.11 & 0.83 & 0.41 & - & - & - & 2.34 & 1.55 & 88.43 \\
\hline & \multicolumn{11}{|c|}{$40-60 \mathrm{~cm}$} \\
\hline $\mathrm{SC}$ & 1.29 & 0.93 & 0.05 & 0.43 & 0.38 & - & - & - & 2.05 & 1.51 & 91.62 \\
\hline E1 & 1.37 & 0.77 & 0.03 & 0.50 & 0.18 & - & - & - & 2.03 & 1.52 & 87.55 \\
\hline E3 & 1.17 & 0.95 & 0.05 & 0.54 & 0.35 & - & - & - & 1.94 & 1.52 & 89.94 \\
\hline \multirow[t]{2}{*}{ E6 } & 1.13 & 1.16 & 0.05 & 0.58 & 0.19 & - & - & - & 2.00 & 1.51 & 91.83 \\
\hline & \multicolumn{11}{|c|}{$60-80 \mathrm{~cm}$} \\
\hline $\mathrm{SC}$ & 1.36 & 0.71 & 0.04 & 0.35 & 0.29 & - & - & - & 1.88 & 1.50 & 91.19 \\
\hline E1 & 1.22 & 0.60 & 0.03 & 0.31 & 0.24 & - & - & - & 1.78 & 1.48 & 87.95 \\
\hline E3 & 1.24 & 1.00 & 0.05 & 0.44 & 0.19 & - & - & - & 1.69 & 1.48 & 87.90 \\
\hline E6 & 1.17 & 0.79 & 0.03 & 0.36 & 0.40 & - & - & - & 1.84 & 1.52 & 84.64 \\
\hline $\begin{array}{l}\mathrm{SC}-\text { sugarca } \\
\text { Bulk density } \\
\text { biomass carb } \\
(\mathrm{mm}) \text {, GMD } \\
\mathrm{SC} \text { - área de } \\
\text { eucalipto por } \\
\text { recalcitrante } \\
\text { solo (mg CO }\end{array}$ & $\begin{array}{l}\text { - Geom } \\
\text { monocu }\end{array}$ & $\begin{array}{l}\text { e area, } \\
- \text { Soil o } \\
- \text { Meta } \\
\text { hean dia } \\
\text { om can }\end{array}$ & $\begin{array}{l}\text { (motient }), \\
\text { çúcar, }\end{array}$ & $\begin{array}{l}\text { icalypt t } \\
\left.\mathrm{g}^{-1}\right), \mathrm{TN} \\
\mathrm{O}_{2} \mathrm{mg}^{-1} \\
\text { ggregat } \\
\text { a cultiv }\end{array}$ & $\begin{array}{l}\text { I nitroge } \\
\text { niay } \\
\left.\text { lay }^{-1}\right), \mathrm{C} \\
\text { ity inde } \\
m \text { eucal }\end{array}$ & 1 ano, & $\begin{array}{l}\text { ypt for } 3 \\
\text { bile } \mathrm{C}(\mathrm{d} \\
\text { piration } \\
\text { rea culti }\end{array}$ & $\begin{array}{l}\text {, E6-area } \\
-1), \mathrm{RC}-\mathrm{R} \\
\mathrm{CO}_{2} \mathrm{~g}^{-1} \text { soil }^{-} \\
\text {com eucali } \\
\text { io total (da }\end{array}$ & $\begin{array}{l}\text { tivated el } \\
\text { citrant C } \\
\text { IWD - M } \\
\text { oor } 3 \text { ano }\end{array}$ & $\begin{array}{l}\text { for } 6 \mathrm{y} \\
\left.\mathrm{kg}^{-1}\right), \mathrm{MB} \\
\text { veighted- } \\
\text { - área cu }\end{array}$ & $\begin{array}{l}\mathrm{DD}- \\
\text { licrobial } \\
\text { ter } \\
\text { la com } \\
\text { C-C } \\
\text { no do }\end{array}$ \\
\hline
\end{tabular}

Revista Árvore 2021;45:e4517 
Table 2 - Eigenvalues, percentage of total explained variance and probability of Hotelling test in multivariate analysis of variance at different depths of soil in areas under sugarcane and eucalypt cultivation in the Atlantic Forest region of the state of Alagoas, Brazil.

Tabela 2 - Valores próprios, porcentagem da variância total explicada e probabilidade do teste de Hotelling na análise multivariada de variância em diferentes profundidades do solo em áreas sob cultivos de cana-de-açúcar e eucalipto na região da Mata Atlântica do estado de Alagoas, Brasil.

\begin{tabular}{|c|c|c|c|c|c|c|c|c|c|c|c|c|}
\hline & \multicolumn{12}{|c|}{ Layers $(\mathrm{cm})$} \\
\hline & \multicolumn{2}{|c|}{$0-10$} & \multicolumn{2}{|c|}{$10-20$} & \multicolumn{2}{|c|}{$20-30$} & \multicolumn{2}{|c|}{$30-40$} & \multicolumn{2}{|c|}{$40-60$} & \multicolumn{2}{|c|}{$60-80$} \\
\hline & $\mathrm{PC}_{1}$ & $\mathrm{PC}_{2}$ & $\mathrm{PC}_{1}$ & $\mathrm{PC}_{2}$ & $\mathrm{PC}_{1}$ & $\mathrm{PC}_{2}$ & $\mathrm{PC}_{1}$ & $\mathrm{PC}_{2}$ & $\mathrm{PC}_{1}$ & $\mathrm{PC}_{2}$ & $\mathrm{PC}_{1}$ & $\mathrm{PC}_{2}$ \\
\hline$\lambda$ & 5.76 & 2.69 & 6.35 & 2.92 & 7.75 & 2.97 & 6.62 & 1.03 & 1.03 & 4.38 & 2.00 & 3.38 \\
\hline$\sigma^{2 \%} \%$ & 63.95 & 29.86 & 63.50 & 29.15 & 57.53 & 29.69 & 82.78 & 12.88 & 12.88 & 62.55 & 28.51 & 56.39 \\
\hline $\mathrm{T}^{2}$ & $3.5 \mathrm{E}-3^{* *}$ & $1.7 \mathrm{E}-3^{* * *}$ & $1.0 \mathrm{E}-6^{* *}$ & $4.2 \mathrm{E}-8^{* * *}$ & $4.2 \mathrm{E}-6^{* *}$ & $8.7 \mathrm{E}-6^{* *}$ & $1.5 \mathrm{E}-3^{* *}$ & $0.56^{\mathrm{ns}}$ & $1.9 \mathrm{E}-3^{* *}$ & $0.69^{\text {ns }}$ & $5.3 \mathrm{E}-4^{* * *}$ & $0.42^{\mathrm{ns}}$ \\
\hline
\end{tabular}

\section{RESULTS}

Mean values of the physical, chemical and biological parameters of soil in different layers and soil management systems evaluated are shown in Table 1 . The results show that soil quality improved after the conversion of sugarcane into eucalypt cultivation in a long-term period, especially the mean values of SOC content with $20.83 \%$ and $23.55 \%$; and TN with $16.25 \%$ and $47.08 \%$ in E3 and E6 systems, respectively. Moreover, BD showed a reduction of $7.14 \%$ and $10.63 \%$ in $\mathrm{E} 3$ and $\mathrm{E} 6$ systems, respectively.

According to the principal component analysis, our dataset was reduced to two dimensions represented by the two first principal components $\left(\mathrm{PC}_{1}\right.$ and $\left.\mathrm{PC}_{2}\right)$,

Table 3 - Correlation quotient between original variables and principal components (PC) in different soil layers in areas under sugarcane and eucalypt cultivation in the Atlantic Forest region of the state of Alagoas, Brazil.

Tabela 3 - Quociente de correlação entre variáveis originais e componentes principais (CP) em diferentes camadas de solo em áreas sob cultivos de cana-de-açúcar e eucalipto na região da Mata Atlântica do estado de Alagoas, Brasil.

\begin{tabular}{|c|c|c|c|c|c|c|c|c|c|c|c|}
\hline \multirow{2}{*}{$\begin{array}{l}\text { Principal } \\
\text { Components } \\
\left(\mathrm{PC}_{\mathrm{s}}\right)\end{array}$} & \multicolumn{11}{|c|}{ Variables } \\
\hline & $\mathrm{BD}$ & SOC & $\mathrm{TN}$ & $\mathrm{LC}$ & $\mathrm{RC}$ & $\mathrm{MBC}$ & $\mathrm{qCO}_{2}$ & $\mathrm{C}-\mathrm{CO}_{2}$ & MWD & GMD & ASI \\
\hline & \multicolumn{11}{|c|}{$0-10 \mathrm{~cm}$} \\
\hline $\mathrm{PC}_{1}$ & 0.59 & $-0.97^{*}$ & - & - & $-0.79^{*}$ & $0.92^{*}$ & -0.04 & $-0.87^{*}$ & $-0.94^{*}$ & $-0.91^{*}$ & $-0.72^{*}$ \\
\hline \multirow[t]{2}{*}{$\mathrm{PC}_{2}$} & $-0.72^{*}$ & 0.15 & - & - & 0.38 & 0.33 & $-0.99^{*}$ & -0.38 & -0.34 & -0.41 & 0.68 \\
\hline & \multicolumn{11}{|c|}{$10-20 \mathrm{~cm}$} \\
\hline $\mathrm{PC}_{1}$ & $0.96^{*}$ & $-0.84^{*}$ & $-0.91^{*}$ & $-0.98^{*}$ & - & $-0.87^{*}$ & $0.81^{*}$ & 0.66 & -0.61 & $-0.78^{*}$ & -0.33 \\
\hline \multirow[t]{2}{*}{$\mathrm{PC}_{2}$} & -0.18 & -0.17 & 0.41 & -0.10 & - & 0.01 & -0.59 & $-0.70^{*}$ & $-0.74^{*}$ & -0.63 & $-0.94^{*}$ \\
\hline & \multicolumn{11}{|c|}{$20-30 \mathrm{~cm}$} \\
\hline $\mathrm{PC}_{1}$ & $0.82^{*}$ & $-0.89^{*}$ & $-0.92^{*}$ & $-0.79^{*}$ & - & 0.19 & $-0.95^{*}$ & 0.23 & $-0.91^{*}$ & $-0.97^{*}$ & 0.28 \\
\hline \multirow[t]{2}{*}{$\mathrm{PC}_{2}$} & 0.15 & -0.15 & 0.10 & -0.52 & - & $-0.87^{*}$ & 0.06 & $-0.97^{*}$ & -0.25 & 0.10 & $-0.94^{*}$ \\
\hline & \multicolumn{11}{|c|}{$30-40 \mathrm{~cm}$} \\
\hline $\mathrm{PC}_{1}$ & $0.93^{*}$ & $-0,93^{*}$ & $-0.96^{*}$ & $-0.99^{*}$ & $-0.91^{*}$ & - & - & - & $-0.96^{*}$ & $-1.00^{*}$ & -0.51 \\
\hline \multirow[t]{2}{*}{$\mathrm{PC}_{2}$} & 0.31 & 0.24 & 0.18 & 0.13 & 0.30 & - & - & - & -0.12 & 0.04 & $-0.85^{*}$ \\
\hline & \multicolumn{11}{|c|}{$40-60 \mathrm{~cm}$} \\
\hline $\mathrm{PC}_{1}$ & $-0.90^{*}$ & $0.94^{*}$ & $0.87^{*}$ & 0.36 & 0.29 & - & - & - & - & $-0.92^{*}$ & $0.93^{*}$ \\
\hline \multirow[t]{2}{*}{$\mathrm{PC}_{2}$} & -0.31 & 0.31 & -0.40 & $0.88^{*}$ & $-0.89^{*}$ & - & - & - & - & 0.06 & -0.24 \\
\hline & \multicolumn{11}{|c|}{$60-80 \mathrm{~cm}$} \\
\hline $\mathrm{PC}_{1}$ & -0.17 & $0.98^{*}$ & $0.91^{*}$ & $0.98^{*}$ & - & - & - & - & $-0,77^{*}$ & - & -0.16 \\
\hline $\mathrm{PC}_{2}$ & $-0.98^{*}$ & -0.01 & -0.42 & -0.14 & - & - & - & - & -0.27 & & $-0.95^{*}$ \\
\hline
\end{tabular}



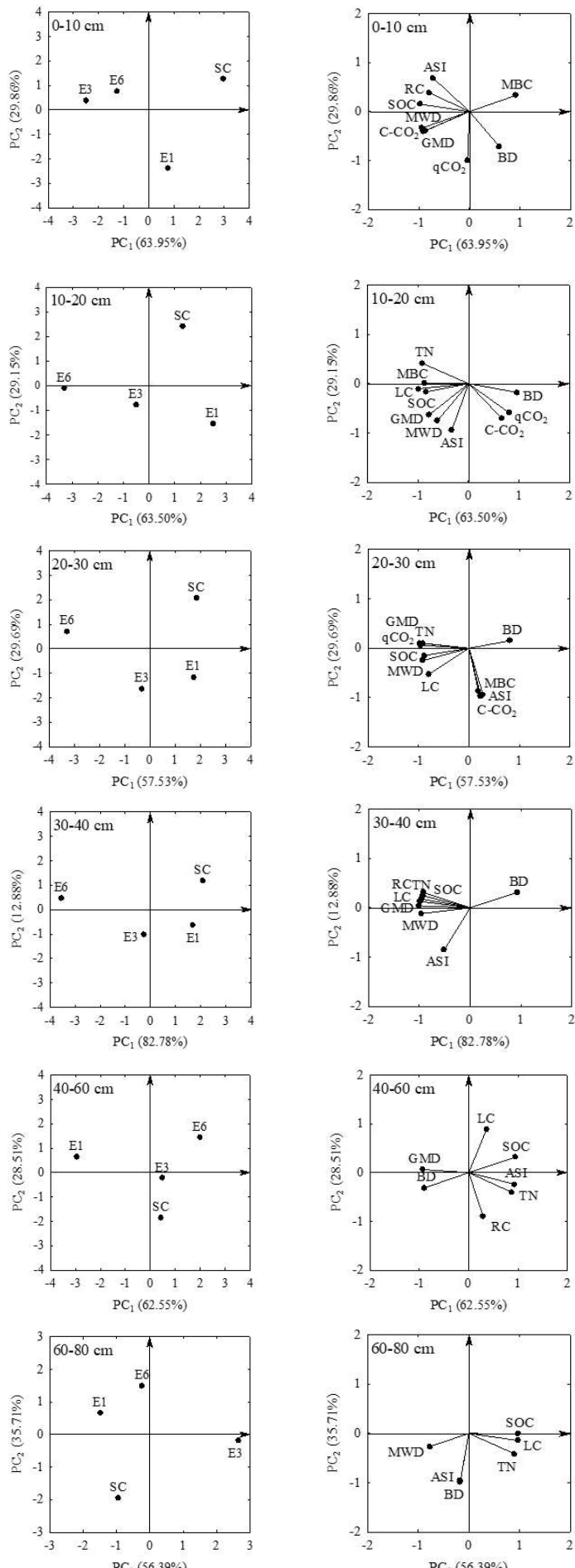

Figure 1 - Two-dimensional projection of systems evaluated and physical-chemical variables of soil in different layers in areas under sugarcane and eucalypt cultivation in the Atlantic Forest region of the state of Alagoas, Brazil.

Figura 1 - Projeção bidimensional de sistemas avaliados e variáveis físico-químicas do solo em diferentes camadas em áreas sob cultivos de cana-de-açúcar e eucalipto na região da Mata Atlântica do estado de Alagoas, Brasil.

\section{Revista Árvore 2021;45:e4517}




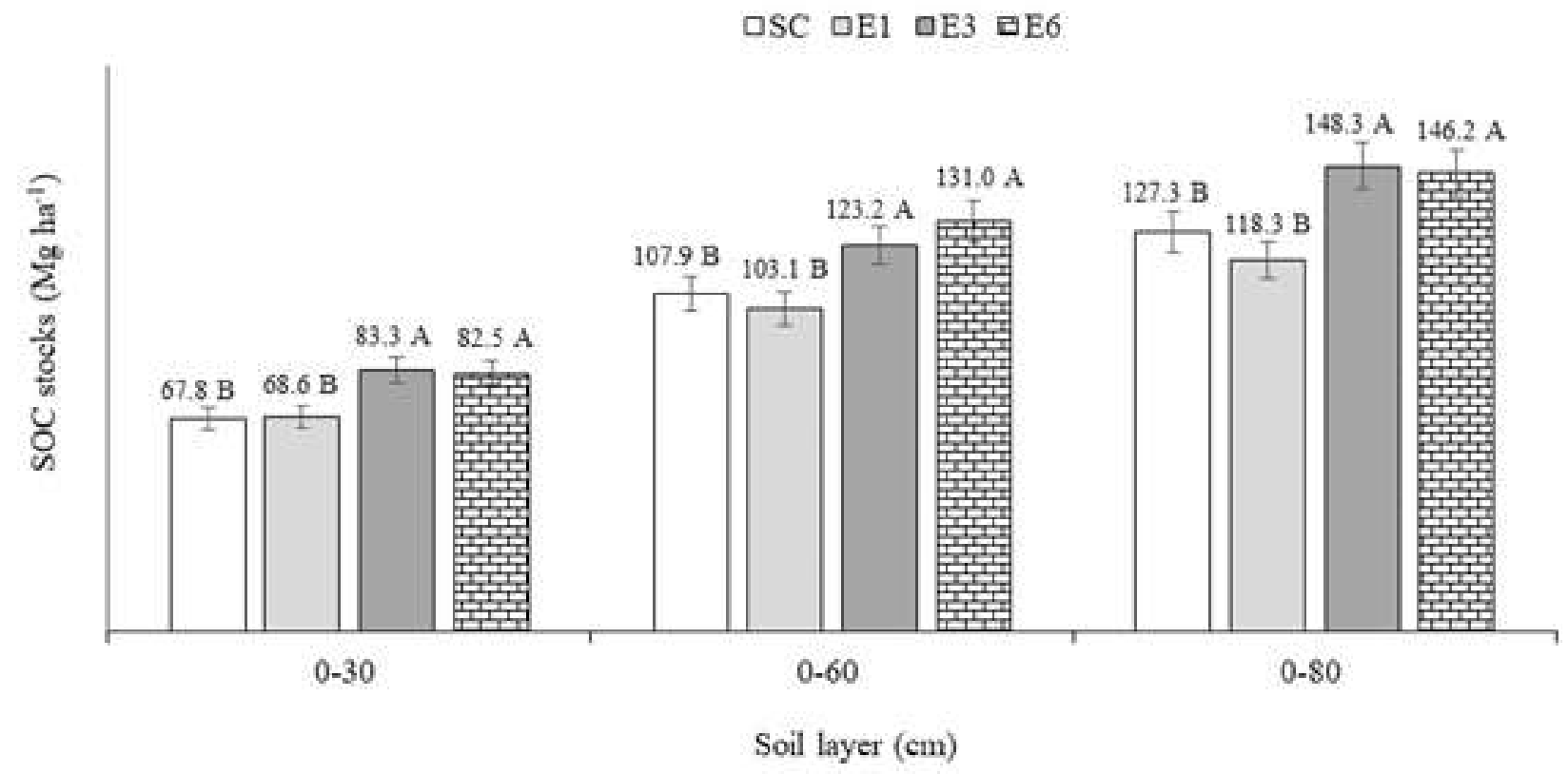

Figure 2 - Soil organic carbon stocks $\left(\mathrm{Mg} \mathrm{ha}^{-1}\right)$ under cultivation of sugarcane (SC) and eucalypt plantations at 1 year (E1), 3 years (E3) and 6 years (E6) in the Atlantic Forest region of the state of Alagoas, Brazil. Different letters indicate significant differences between land-use systems by Tukey's test at $5 \%$ probability.

Figura 2 - Estoque de carbono orgânico do solo $\left(M g h a^{-1}\right)$ sob cultivos de cana-de-açúcar (SC) e plantações de eucalipto com 1 ano (E1), 3 anos (E3) e 6 anos (E6) na região da Mata Atlântica do estado de Alagoas, Brasil. Letras diferentes indicam diferenças significativas entre os sistemas de uso da terra pelo teste de Tukey a $5 \%$ de probabilidade.

with eigenvalues higher than one $(\lambda>1.00)$ for all soil layers. The PCs explained $87.22 \%$ to $93.81 \%$ of total variance. The first principal component $\left(\mathrm{PC}_{1}\right)$ was responsible for $63.95 \%$ to $28.51 \%$ of the variance in the soil layers of $0-10 \mathrm{~cm}$ and $60-80 \mathrm{~cm}$, respectively, while the second component $\left(\mathrm{PC}_{2}\right)$ was responsible for $29.86 \%$ to $56.39 \%$ of variance considering the same soil layers, respectively. Hotelling test shows that for the $\mathrm{PC}_{1}$ there was a significant difference $(\mathrm{p}<$ 0.01 ) between land-use systems in all layers, whereas for the $\mathrm{PC}_{2}$, the differences were observed only up to $30 \mathrm{~cm}$ (Table 2).

The results of multivariate analysis of variance for the correlation between original variables and $\mathrm{PC}$ showed that factors $(\mathrm{r})$ varied between $>10.70 \mid\left(\mathrm{PC}_{1}\right)$ in $0-10 \mathrm{~cm}$ layer and $>|0.95|\left(\mathrm{PC}_{2}\right)$ in $60-80 \mathrm{~cm}$ layers, indicating that all variables had a strong correlation (Table 3).

In general terms, the results show that $\mathrm{PC}_{1}$ was formed by increasing SOC, LC, TN, GMD, MWD and ASI contents and reducing $\mathrm{MBC}$ and $\mathrm{BD}$ in different soil layers of E3 and E6 systems. That behavior occurred differently in $\mathrm{SC}$ and $\mathrm{E} 1$ systems. $\mathrm{PC}_{2}$ was formed by the highest values of $\mathrm{BD}, \mathrm{qCO}_{2}$ and $\mathrm{C}-\mathrm{CO}_{2}$ in $\mathrm{E} 1$ and $\mathrm{SC}$ systems, whereas E3 and E6 systems had the highest values of ASI, MWD and LC (Figure $1)$.

With regard specifically to SOC stocks, our results showed (Figure 2) that cultivation with eucalypt with three and six years was already sufficient to promote a significant $(p<0.05)$ increase in SOC stocks, when compared to the sugarcane system. The area E3 showed increases of $22.8 \%, 14.2 \%$ and $16.4 \%$, in layers $0-30,0-60$ and $0-80 \mathrm{~cm}$, respectively; while the area E6, increases in SOC stocks were equal to $21.6 \%, 21.4 \%$ and $14.8 \%$, respectively, in comparison to sugarcane system.

\section{DISCUSSION}

According to PCA results (Table 3), up to 30-40 $\mathrm{cm}$ layers, the first component $\left(\mathrm{PC}_{1}\right)$ was formed by a process of increasing $\mathrm{SOC}, \mathrm{TN}$ and soil aggregates (MWD, GMD and ASI) in areas of eucalypt (E3 and E6). These results show that changes in SOC content after forest establishment often vary due to the time of land-use, land-use background, soil type and texture

Revista Árvore 2021;45:e4517 
(Hernández et al., 2016). For example, Vicente et al. (2016) observed SOC reductions in $0-100 \mathrm{~cm}$ layer after conversion of pasture $(176 \mathrm{Mg} \mathrm{C} \mathrm{ha-1)} \mathrm{into}$ eucalypt (Eucalyptus spp.) with $3\left(148 \mathrm{Mg} \mathrm{C} \mathrm{ha}^{-1}\right)$ and 5 years $\left(160 \mathrm{Mg} \mathrm{C} \mathrm{ha}^{-1}\right)$ of implementation in Brazil. Lima et al. (2006) observed an increase of $49.75 \%$ in SOC stocks in 0-20 cm layer after the conversion of degraded pasture into eucalypt (Eucalyptus spp.) in Brazil. In our case, the results indicate that the conversion of areas conventionally cultivated with sugarcane to eucalypt represents a management alternative with the potential to accumulate SOC, varying between $14.21 \%$ and $22.83 \%$, contributing to mitigate GHG emissions (Figure 2).

This behavior is extremely relevant for soil quality recovery, which was lost after 20 years of sugarcane cultivation, since the increase in SOC (Table 1 and Figure 2) positively influences the physical, chemical and biological properties of soil (Cook et al., 2016; Zhang et al., 2019).

Increases in SOC and TN (Table 1) found in the present study are positively correlated $(\geq 0.70)$ with increments in labile carbon (LC) and recalcitrant carbon (RC), which probably contributed to the improvement in the stability of soil aggregates, which is confirmed by the high values found for MWD, GMD and ASI (Table 1). However, the opposite was observed in eucalypt area E1 and SC. Thus, these results rectify the information stated by Cook et al. (2016), when they affirm that SOC increases in tropical agricultural areas are important, since plant residues are source of nutrients and increase cation exchange capacity, soil aggregation and infiltration of water, reducing surface runoff and improving water holding capacity and microorganism activity.

Regarding $\mathrm{PC}_{2}$ formation up to $30-40 \mathrm{~cm}$ layers, it represents an average of $25.40 \%$ of total experimental variance (Table 2) and it was characterized by the increase of $\mathrm{MBC}, \mathrm{C}-\mathrm{CO}_{2}$ and $\mathrm{qCO}_{2}$ in $\mathrm{E} 1$ and $\mathrm{SC}$ areas, which can be indicative of an unbalanced environment, probably related to microbial activity, as well as the highest levels of $\mathrm{BD}$ and low aggregate stability of soil.

In deeper soil layers (40-60 and 60-80 cm), $\mathrm{PC}_{1}$ (an average of $59.50 \%$ of total experimental variance) is formed by the increase of $\mathrm{BD}, \mathrm{MWD}$, GMD and $\mathrm{ASI}$ in $\mathrm{E} 1$ and $\mathrm{SC}$ areas, whereas $\mathrm{PC}_{1}$ (with an average of $20.70 \%$ of total experimental variance) is characterized by the increase of chemical properties of soil (SOC, TN, LC and RC) in E3 and E6 areas (Table 2 and Figure 1). These results converge with those found by Gatto et al. (2010) and Santos et al. (2013), who also observed an improvement of soil quality in areas cultivated with eucalypt (Eucalyptus spp.). According to Cook et al. (2016), in general, the increase of SOC and the improvement of soil structure in planted forests are common (due to high production of biomass above- and belowground), continuous contribution of organic recalcitrant residues and a deeper root system.

The $\mathrm{BD}$ reduction and the increase of soil aggregates (MWD, GMD and ASI) found in E3 and E6 areas (Table 1) show that, despite the previous cultivation with sugarcane, over 3 years without intense anthropic actions, such as plowing and traffic of machinery, as well as organic residues input on soil surface due to the growth and development of trees (Barreto et al., 2014; Zhang et al., 2019), are enough to improve physical quality of soil and, consequently, other properties, resulting in recovery of its structure (Rodrigues et al., 2013; Ibiapina et al., 2014).

These results are extremely important to the environment because eucalypt areas that show high aggregate stability are benefited, resulting in the recovery of the physical properties of soil, such as porosity, high infiltration, and water retention, being resistant to soil erosion, which contributes to physical and chemical protection of SOM (Barreto et al., 2014; Ibiapina et al., 2014; Zhang et al., 2019). Our results are in accordance with those reported by Vicente et al. (2019), since they found larger microaggregates (2000-250 $\mu \mathrm{m})$ in eucalypt (Eucalyptus spp.) areas (3 and 5 years of cultivation) in comparison to pasture and native forest areas, in Brazil.

During the recovery of soil properties, a substantial increase occurred in the physical, chemical and biological parameters in eucalypt cultivated areas (E3 and E6), which is justified by several factors, for example, the continuous input of plant residues to the surface layer, the microclimate formed by the trees, which reduces direct contact of the solar rays, and the impact of rain on soil (Ibiapina et al., 2014; Zhang et al., 2019). Furthermore, the quality of organic residues also contributes to this behavior, since woody residues, such as litter, have higher concentration of

Revista Árvore 2021;45:e4517 
phenols, cellulose and lignin; their decomposition supplies more nutrients to soil and to microorganisms (Barreto et al., 2014; Cook et al., 2016).

These factors result in maintenance of uniform soil temperature and moisture overtime, which promotes a better development of root system and microorganism activity as well as a reduction of SOM mineralization in eucalypt forests (Rodrigues et al., 2013; Ibiapina et al., 2014). In this context, our results show that a correct management in eucalypt cultivation reduces $\mathrm{BD}$ and promotes a recovery of SOC, TN and biological parameters of soil, pointing to the great potential of planted forests in the sequestration of SOC (Table 1 and Figure 2).

The results of SOC stocks showed that the conversion from sugarcane cultivation to eucalypt plantations substantially increases $(p<0.05)$ SOC (Figure 2), both in the surface layer $(0-30 \mathrm{~cm})$ and in the deeper layers $(0-60$ and 0-80 cm). The differences between SOC stocks become clear already from the third year of cultivation (E3) and increases with eucalypt stand age (E6). Our results are similar to those found in other studies. For instance, Guedes et al. (2018) found the greatest carbon stocks of plant biomass (202.5 $\mathrm{Mg} \mathrm{C} \mathrm{ha}^{-1}$ ) and soil (138.8 $\mathrm{Mg} \mathrm{C}^{-}$ ${ }^{1}$ ) in eucalypt (Eucalyptus spp.) when compared to Pinus forest (162.1 and 135.2 $\mathrm{Mg} \mathrm{C} \mathrm{ha}^{-1}$ ) and native forest (17.9 and $87.3 \mathrm{Mg} \mathrm{C} \mathrm{ha}^{-1}$ ) in 0-50 cm layer, in Mozambique. Similarly, Ibiapina et al. (2014) observed increases in SOC stocks in 0-30 cm layer, in eucalypt areas (Eucalyptus spp.) with 2 (49.9 Mg $\left.\mathrm{C} \mathrm{ha} \mathrm{h}^{-1}\right)$ and 4 years $\left(68.3 \mathrm{Mg} \mathrm{C} \mathrm{ha}^{-1}\right)$ in comparison to the area traditionally cultivated with soybean $(25.7$ $\left.\mathrm{Mg} \mathrm{C} \mathrm{ha}{ }^{-1}\right)$ and native forests $\left(45.8 \mathrm{Mg} \mathrm{C} \mathrm{ha}^{-1}\right)$. In this context, according to Zhang et al. (2019), considering the growth of trees in planted forests, carbon in both biomass and soil can be rapidly recovered or even exceed that of native forests.

On the other hand, higher results of $\mathrm{BD}$ and lower aggregation of soil that were found in the first layers of SC and E1 areas (Table 1) are related to destabilization of soil structure. In SC, this effect can be attributed to the traditional management of plowing of soil and burning of straw, which resulted in the reduction of organic residues during the cultivation of this area (Rossetti et al., 2014). These results are in accordance with those reported by Ibiapina et al.
(2014), who found lower values of soil aggregates (MWD, GMD and ASI) in the area conventionally cultivated with soybean in comparison to eucalypt and native forest areas. In E1, these behaviors are due to the management practice adopted during the previous period cultivated with SC. Moreover, for planting eucalypt seeds, a deep plowing was performed in the soil, which exposed SOM stored in deep layers to microbial actions. Another fact to be highlighted is related to young trees ( 1 year), in which organic residues are reduced when compared to older trees (Barreto et al., 2014; Cook et al., 2016). In agricultural areas that have fragile aggregates in soil, especially in the superficial layer, there is a probability that they disappear and disperse due to the strong impact of rain (Medeiros et al., 2018).

Regarding the best results of eucalypt plantations (E3 and E6), only up to 30-40 cm layers (Table 1), can be attributed to the short period of cultivation in these areas, in which organic residues (leaves, branches and barks of trees) and the highest fine root density were not enough to increase physical, chemical and biological properties in the deeper layers of soil (Barreto et al., 2014; Zhang et al., 2019).

\section{CONCLUSIONS}

Our results show that the conversion of sugarcane cultivation with burning of straw and manual harvest into eucalypt plantations in Atlantic Forest region of Brazil was efficient at promoting SOC sequestration and improving physical, chemical and biological attributes of soil. Principal components analysis (PCA) highlighted the differences between sugarcane and eucalypt cultivation in the surface layers of soil (up to $40 \mathrm{~cm}$ ). Furthermore, it was clear that the eucalypt area with 6 years (E6) had the best results when compared to other land-use systems, indicating the role of time for improving soil attributes. Finally, the replacement of sugarcane cultivation with burning with eucalypt plantations presents itself as a management alternative capable of promoting the sequestration of atmospheric $\mathrm{CO}_{2}$, contributing to mitigate global warming, and also a possibility of diversifying land-use, using, for example, hillside areas where sugarcane productivity is lower and harvesting is more difficult. However, more studies are necessary in order to evaluate the impacts of the conversion of sugarcane cultivation to eucalypt 
plantations in a long-term, to confirm whether these improvements remain over time.

\section{AUTHOR CONTRIBUTIONS}

The manuscript is part of the master's dissertation of the author Silva, A.V.L.

Maia, S.M.F. and Silva, A.V.L. contributed to the study conception and design.

Material preparation, data collection and analysis were performed by Silva, A.V.L.; Medeiros, A.S.; Silva, T.S.; and Maia, S.M.F.

Medeiros, A.S.; Silva, T.S.; Ferraz, R.L.S.; Silva, A.V.L. and Maia, S.M.F. designed the methodology, analyzed the data, and contributed to the writing.

All authors read and approved the final manuscript.

\section{REFERENCES}

Anderson JPE. Soil Respiration. In: Page AL, Miller RH, Keeney DR, editors. Methods of soil analysis, $2^{\mathrm{a}}$ ed. Madison, Wisconsin: Soil Science Society of America/American Society of Agronomy; 1982. p. 831-866.

Barreto PAB, Gama-Rodrigues EF, Gama-Rodrigues AC. Carbon in organic matter fraction in soils under eucalyptus plantation at different ages. Scientia Forestalis. 2014; 42(104): 581-90.

Cavalli JP, Reichert JM, Rodrigues MF, Araújo EF. Composition and functional soil properties of arenosols and acrisols: Effects on eucalyptus growth and productivity. Soil and Tillage Research. 2020; 196:1-10. doi:10.1016/j.still.2019.104439

Chan KY, Bowman A, Oates A. Oxidizible organic carbon fractions and soil quality changes in an oxic paleustalf under different pasture leys. Soil Science. 2001; 166(1): 61-67.

Companhia Nacional de Abastecimento CONAB. Cana-de-açúcar. Safra 2016/ 2017. Terceiro levantamento dezembro de 2016. 2016. [cited 2020 abr. 6]. Available from: http:// http://www.conab.gov.br/OlalaCMS/uploads/ arquivos/16_12_27_16_30_01_boletim_cana portugues_-3o_lev_-_ $1 \overline{6}-1 \overline{7} \cdot \mathrm{pdf}$
Cook RL, Binkley D, Stape JL. Eucalyptus plantation effects on soil carbon after 20 years and three rotations in Brazil. Forest Ecology and Management. 2016; 359:92-98. doi: 10.1016/j. foreco.2015.09.035

Empresa Brasileira de Pesquisa Agropecuária EMBRAPA. Manual de Métodos de Análise de Solo. $2^{\mathrm{a}}$ ed. Rio de Janeiro, RJ: Centro Nacional de Pesquisa de Solos.1997. 212p.

Empresa Brasileira de Pesquisa Agropecuária EMBRAPA. Zoneamento agroecológico do estado de Alagoas - ZAAL. 2012. [cited 2020 abr. 2]. Available from: http://www.uep.cnps.embrapa.br/zaal/imagens/ MapasSolos/Solos_Sao\%20Miguel.jpg.

IUSS Working Group WRB-FAO. 2015. IUSS Working Group WRB. 2015. World Reference Base for Soil Resources 2014, update 2015 International soil classification system for naming soils and creating legends for soil maps. World Soil Resources Reports No. 106. FAO, Rome. [cited 2020 abr. 5]. Available from: http://www.fao.org/3/i3794en/ I3794en.pdf.

Ferreira AS, Camargo FAO, Vidor C. Use of microwave radiation to evaluate soil microbial biomass. Revista Brasileira de Ciência do Solo. 1999; 23(4): 991-996. doi:10.1590/S010006831999000400026

Gama-Rodrigues EF, Barros NF, Viana AP, Santos GA. Microbial biomass and activity in soil and forest litter of eucalyptus plantations and native vegetation in southeastern Brazil. Revista Brasileira de Ciência do Solo. 2008; 32(4): 1489-1499. doi:10.1590/ S0100-06832008000400013.

Gatto A, Barros NF, Novais RF, Silva IR, Leite HG, Leite FP, et al. Carbon storage in the soil and in the biomass of eucalypt plantations. Revista Brasileira de Ciência do Solo. 2010; 34(4):1069-1079. doi: 10.1590/S0100-06832010000400007

Guedes BS, Olsson BA, Egnell G, Sitoe AA, Karltun E. Plantations of Pinus and Eucalyptus replacing degraded mountain miombo woodlands in Mozambique significantly increase carbon sequestration. Global Ecology and Conservation. 2018; 14:e00401. doi: 10.1016/j.gecco.2018.e00401

Guedes BS, Olsson BA, Karltun E. Effects of 34-year-old Pinus taeda and Eucalyptus grandis 
plantations on soil carbon and nutrient status in former miombo forest soils. Global Ecology and Conservation. 2016; 8:190-202. doi:10.1016/j. gecco.2016.09.005

Govaerts B, Sayre KD, Lichter K, Dendooven L, Deckers J. Influence of permanent raised bed planting and residue management on physical and chemical soil quality in rain fed maize/ wheat systems. Plant and Soil. 2007; 291:39-54. doi:10.1007/s11104-006-9172-6

Hair FJ, Black WC, Babin BJ, Anderson RE, Tatham RL. Análise Multivariada de Dados. Porto Alegre, RS: Bookman; 2009.

Hernández J, Del Pino A, Vance ED, Califra Á, Del Giorgio F, Martínez L, et al. Eucalyptus and Pinus stand density effects on soil carbon sequestration. Forest Ecology and Management. 2016; 368: 28-38. doi:10.1016/j.foreco.2016.03.007

Indústria Brasileira de Árvores - IBÁ. Estatística da indústria brasileira de árvores. 2017. 2017 [cited 2020 abr. 6]. Edition 25. Available from: https://iba. org/eng/datafiles/publicacoes/relatorios/iba-relatorioanual2017.pdf

Ibiapina TVB, Salviano AAC, Nunes LAPL, Mousinho FEP, Lima MG, Soares LMS. Resistance to penetration and aggregation of a Yellow Oxisol under monocropping of soybean and eucalyptus in a savannah of Piauí state, Brazil. Científica. 2014; 42 : 411-418. doi:10.5039/agraria.v13i4a5577

Islam KR, Weil RR. Biol Microwave irradiation of soil for routine measurement of microbial biomass carbon. Biology and Fertility of Soils. 1998; 27(4): 408-416. doi: 10.1007/s003740050451

Kaiser HF. The application of electronic computers to factor analysis. Educational and Psychological Measurement. 1960; 20: 141-151. doi: $10.1177 / 001316446002000116$

Köppen W. Klassification der klimate nach temperature, niederschlag und jahreslauf. Petermanns Geographische Mitteilungen. 1918; 64:193-203.

Korchagin J, Bortoluzzi EC, Moterle DF, Petry C, Caner L. Evidences of soil geochemistry and mineralogy changes caused by eucalyptus rhizosphere. Catena. 2019; 175: 132-143. doi:10.1016/j.catena.2018.12.001

Lima AMN, Silva IR, Neves JCL, Novais RF, Barros NF, Mendonça ES, et al. Soil organic carbon dynamics following afforestation of degraded pastures with eucalyptus in southeastern Brazil. Forest Ecology and Management. 2006; 235(1-3):219-231. https://doi.org/10.1016/j. foreco.2006.08.331.

Medeiros AS, Silva TS, Silva AVL, Barros DRS, Maia SMF. Organic carbon, nitrogen and the stability of soil aggregates in areas converted from sugar cane to eucalyptus in the state of Alagoas. Revista Árvore. 2018; 42: e420404. doi:10.1590/180690882018000400004

Mendonça ES, Matos ES. Matéria orgânica do solo: métodos de análises. Viçosa, MG: UFV; 2005.

Rodrigues LS, Almeida TA, Marino RH, Barretto MCV, Martins MVG, Prata RM. Quality of soils cultivated with eucalyptus in Itaporanga D' Ajuda - Sergipe, Brazil. Revista Brasileira de Ciências Agrárias. 2013; 8(1): 95-101. https://doi.org/10.5039/ agraria.v8i1a1847

Rossetti KV, Teixeira DB, Reis IMS, Centurion JF. Aggregation of an Oxisol in relation to different cultivation cycles of sugarcane under mechanized harvesting. Revista Agro@mbiente. 2014; 8(1): 1017.

Santos DC, Farias MO, Lima CLR, Kunde RJ, Pillon $\mathrm{CN}$, Flores CA. Physical and chemical fractionation of organic matter of an Alfisol under different use systems. Ciência Rural. 2013; 43(5): 838-844. doi:10.1590/S0103-84782013005000037

Sisti CPJ, Santos HP, Kohhann R, Alves BJR, Urquiaga S, Boddey MB. Change in carbon and nitrogen stocks in soil under 13 years of conventional or zero tillage in southern Brazil. Soil and Tillage Research. 2004; 76:39-58. doi:10.1016/j. still.2003.08.007

Souza IF, Barros NF, Novais RF, Vergütz, L, Silva IR. Potential contribution of eucalypt harvest residues to soil organic carbon in Brazil. New Forests. 2020; 51:911-932. doi:10.1007/s11056-01909765-2

Sparling GP, West AW. A direct extraction method 
to estimate soil microbial C: calibration in situ using microbial respiration and 14C labeled cells. Soil Biology and Biochemistry. 1998; 20: 337-343. doi:10.1016/0038-0717(88)90014-4

Statsoft INC. Programa computacional Statistica. Version 7.0. E.A.U. 2004.

Tedesco MJ, Gianello G, Bissani CA, Bohnen H, Volkweis SI. Análise de solo, plantas e outros materiais, $2^{\mathrm{a}}$ ed. Porto Alegre, RS: Universidade Federal do Rio Grande do Sul; 1995. 174 p.

Vicente LC, Gama-Rodrigues EF, Gama-Rodrigues AC. Soil carbon stocks of Ultisols under different land use in the Atlantic rainforest zone of Brazil. Geoderma Regional. 2016; 7:330-337. doi: 10.1016/j.geodrs.2016.06.003
Vicente LC, Gama-Rodrigues EF, Gama-Rodrigues AC, Marciano CR. Organic carbon within soil aggregates under forestry systems and pasture in a southeast region of Brazil. Catena. 2019; 182: 104139. doi:10.1016/j.catena.2019.104139

Yeomans JC, Bremner JM. A rapid and precise method for routine determination of organic carbon in soil. Journal Communications in Soil Science and Plant Analysis. 1988; 19: 1467-1476. doi:10.1080/00103628809368027

Zhang H, Deng Q, Hui D, Wu J, Xiong X, Zhao J, et al. Recovery in soil carbon stock but reduction in carbon stabilization after 56-year forest restoration in degraded tropical lands. Forest Ecology and Management. 2019; 441:1-8. doi:10.1016/j. foreco.2019.03.037 